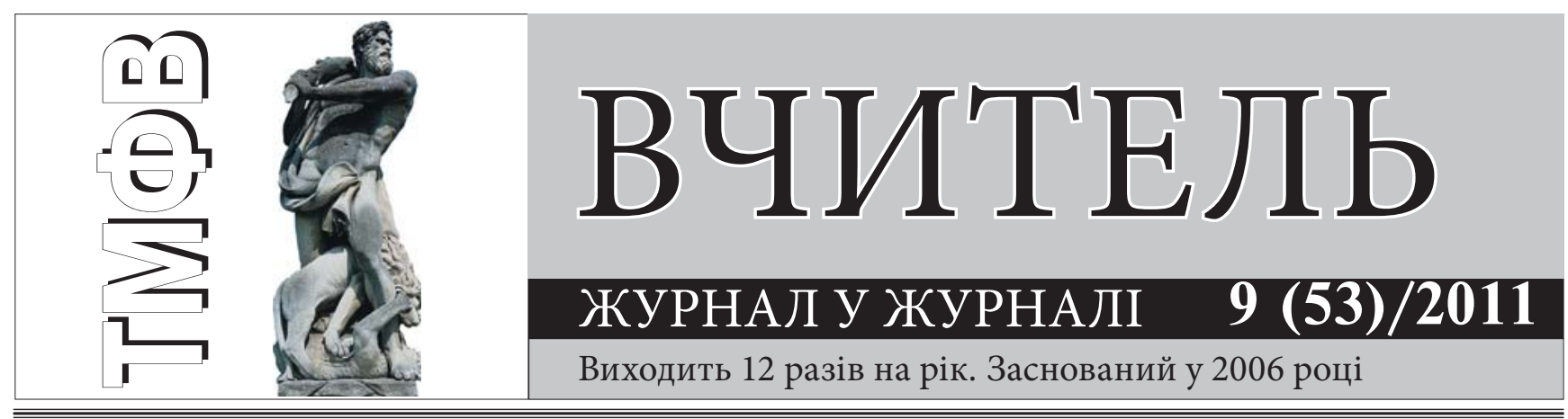

\title{
ПЕДАГОГІЧНА ПРАКТИКА В ШКОЛІ. ПОВІДОМЛЕННЯ ІІ
}

\author{
Худолій О.М., Іващенко О.В. \\ Харківський національний педагогічний університет імені Г.С. Сковороди
}

\begin{abstract}
Анотація. У статті розглядається програма педагогічної практики в середніх класах загальноосвітньої школи. Конкретизуються: мета і завдання практики, тривалість і строки проведення, обов’язки практикантів, зміст роботи, перелік звітної документації. Наводяться зразки оформлення звітної документації та пояснення до ії упорядкування.

Ключові слова: педагогічна практика, програма, документи планування.
\end{abstract}

У повідомленні I були розглянуті програма педагогічної практики в середніх класах і зразки звітної документації. Нижче буде дана характеристика наступним документам:

1. Протокол хронометрування та пульсометрії уроку фізичної культури.

2. Протокол обговорення залікового (контрольного) уроку.

3. Протоколи тестування рухової підготовленості школярів.

4. Робочий план занять в одній із спортивних секцій.

5. Календарний план спортивно-масової роботи школи на півріччя.

6. Положення (сценарій) спортивно-масового заходу.

7. Методична розробка виховного заходу з протоколом його обговорення.

8. Психолого-педагогічна характеристика учня.

9. Звіт про проходження практики.

Документ 7. Протокол хронометрування i пульсометрії уроку фізичної культури.

Кожен учитель фізичної культури повинен прагнути до максимального використання часу на уроці і раціональній витраті його на вирішення педагогічних задач. Одним 3 показників ефективності уроку є його щільність, що характеризує ефективність використання часу уроку.

(c) Худолій О.М., Іващенко О.В., 2011.
Щільність визначають шляхом хронометражу уроку (див. табл. 3.5). Хронометрують такі види діяльності вчителя й учнів:

- виконання учнями вправ (елементи стройових вправ, загальнорозвиваючі вправи, вправи на увагу, танцювальні вправи, підвідні і основні вправи, рухливі ігри, вправи на розвиток рухових здібностей) (графа 5);

- сприйняття (пояснення, вказівки вчителя, виправлення помилок, показ вправ вчителем, спостереження за виконанням вправ) (графа 6);

- відпочинок (чекання виконання наступного завдання, короткочасний відпочинок між підходами для розвитку рухових здібностей) (графа 7);

- допоміжні дії (перестроювання, перехід від одного снаряда до іншого, підготовка місць для занять, прибирання снарядів й інвентарю) (графа 8);

- простоювання з вини вчителя (запізнення класу на урок, передчасне закінчення уроку, пошук інвентарю, приведення в порядок пошкоджений інвентар) (графа 9).

Як об’єкт спостереження вибирають середнього учня, досить активного і дисциплінованого. Секундомір включають по дзвонику на урок і виключають по дзвонику до його закінчення.

Дані спостереження і хронометражу фіксують у протоколі. Під час спостереження уроку безпо- 
Титульний аркуш

«Затверджую»

Memoducm

Оиінка

Протокол

хронометражу й пульсометрї уроку з бізичної культури

Дата проведення класі ЗОШ № м. Харкова

Місце проведення

Урок проводить вчитель

Урок хронометрує

\section{Завдання уроку}

1. Закріпити техніку виконання перекиду вперед.

2. Повторити лазіння по канату в три прийоми.

3. Сприяти розвитку спритності за допомогою гри «П’ятнашки»

\begin{tabular}{|c|c|c|c|c|c|c|c|c|}
\hline 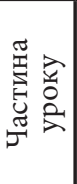 & Вид діяльності & $\begin{array}{c}\text { Час } \\
\text { закінчення } \\
\text { дії }\end{array}$ & 吕 & 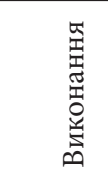 & 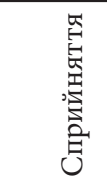 & $\begin{array}{l}\text { 志 } \\
\text { 商: } \\
0 \\
0 \\
0 \\
0\end{array}$ & 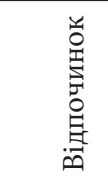 & 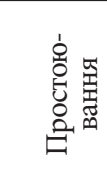 \\
\hline \multirow{18}{*}{$\begin{array}{l}\dot{8} \\
0 \\
0 \\
\tilde{\sigma} \\
\pm \\
5 \\
5 \\
0 \\
\sigma \\
\sigma \\
\sigma \\
5 \\
0 \\
0 \\
0 \\
0 \\
E \\
E \\
ت \\
ت\end{array}$} & Шикування & $22^{\prime} 40^{\prime \prime}$ & & & & & & $2^{\prime} 40^{\prime \prime}$ \\
\hline & $\begin{array}{l}\text { Рапорт чергового, пояснення задач уро- } \\
\text { ку }\end{array}$ & $4^{\prime} 10^{\prime \prime}$ & & & & $11^{\prime} 30^{\prime \prime}$ & & \\
\hline & Стройові вправи & $5^{\prime} 30^{\prime \prime}$ & 12 & $10^{\prime} 20^{\prime \prime}$ & & & & \\
\hline & Ходьба & $6^{\prime} 05^{\prime \prime}$ & & $0 \prime 35^{\prime \prime}$ & & & & \\
\hline & Вправи у русі & $88^{\prime} 00^{\prime \prime}$ & 11 & $15^{\prime \prime}$ & & & & \\
\hline & Біг & $11^{\prime} 15^{\prime \prime}$ & 16 & $33^{\prime \prime} 15^{\prime}$ & & & & \\
\hline & Вправи на дихання & $11^{\prime} 40^{\prime \prime}$ & & $00^{\prime} 25^{\prime \prime}$ & & & & \\
\hline & Перестроювання в колону по три & $12^{\prime} 20^{\prime \prime}$ & & & & $0^{\prime} 40^{\prime \prime}$ & & \\
\hline & Пояснення першої вправи & $12^{\prime} 30^{\prime \prime}$ & & & $0^{\prime} 10^{\prime \prime}$ & & & \\
\hline & Виконання вправи & $13^{\prime} 00^{\prime \prime}$ & 14 & $0^{\prime} 30^{\prime \prime}$ & & & & \\
\hline & Пояснення другої вправи & $13^{\prime} 10^{\prime \prime}$ & & & $00^{\prime} 10^{\prime \prime}$ & & & \\
\hline & Виконання вправи & $13^{\prime} 40^{\prime \prime}$ & & $0 \prime 30^{\prime \prime}$ & & & & \\
\hline & Пояснення третьої вправи & $13^{\prime} 30^{\prime \prime}$ & & & $00^{\prime} 10^{\prime \prime}$ & & & \\
\hline & Виконання вправи & $14^{\prime} 15^{\prime \prime}$ & & $0^{\prime} 25^{\prime \prime}$ & & & & \\
\hline & Виконання вправ потоком & $16^{\prime} 30^{\prime \prime}$ & 16 & $22^{\prime} 15^{\prime \prime}$ & & & & \\
\hline & Ходьба на місці & $16^{\prime} 50^{\prime \prime}$ & & $0 \prime 20^{\prime \prime}$ & & & & \\
\hline & Повороти & $17^{\prime} 00^{\prime \prime}$ & & $00^{\prime} 10^{\prime \prime}$ & & & & \\
\hline & Imoro & & & $11^{\prime} 40^{\prime \prime}$ & $0^{\prime} 30^{\prime \prime}$ & $2^{\prime} 10^{\prime \prime}$ & & $2^{\prime} 40^{\prime \prime}$ \\
\hline \multirow{12}{*}{ 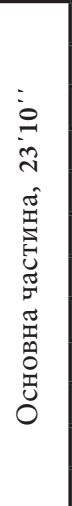 } & Перестроювання по відділеннях & $17^{\prime} 30^{\prime \prime}$ & 13 & & & $0 \prime 30^{\prime \prime}$ & & \\
\hline & Пояснення завдань & $18^{\prime} 20^{\prime \prime}$ & & & $00^{\prime} 50^{\prime \prime}$ & & & \\
\hline & Стрибок & $18^{\prime} 30^{\prime \prime}$ & 11 & $0^{\prime} 10^{\prime \prime}$ & & & & \\
\hline & Чекання черги & $19^{\prime} 20^{\prime \prime}$ & & & & & $0^{\prime} 50^{\prime \prime}$ & \\
\hline & Стрибок & $19^{\prime} 30^{\prime \prime}$ & & $00^{\prime} 10^{\prime \prime}$ & & & & \\
\hline & Пояснення учителя & $19^{\prime} 40^{\prime \prime}$ & & & $00^{\prime} 10^{\prime \prime}$ & & & \\
\hline & Чекання черги & $20^{\prime} 10^{\prime \prime}$ & & & & & $00^{\prime} 30^{\prime \prime}$ & \\
\hline & Стрибок & $20^{\prime} 30^{\prime \prime}$ & 14 & $0 \prime 20^{\prime \prime}$ & & & & \\
\hline & Перестроювання & $20^{\prime} 50^{\prime \prime}$ & & & & $0^{\prime} 20^{\prime \prime}$ & & \\
\hline & Пояснення учителя & $21^{\prime} 05^{\prime \prime}$ & & & $0^{\prime} 15^{\prime \prime}$ & & & \\
\hline & Перекиди & $21^{\prime} 10^{\prime \prime}$ & 15 & $00^{\prime} 05^{\prime \prime}$ & & & & \\
\hline & Пояснення учителя & $21^{\prime} 20^{\prime \prime}$ & & & $0^{\prime} 10^{\prime \prime}$ & & & \\
\hline
\end{tabular}


Худолій О.М., Іващенко О.В. Педагогічна практика в школі. Повідомлення II

\begin{tabular}{|c|c|c|c|c|c|c|c|c|}
\hline 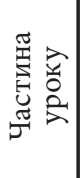 & Вид діяльності & $\begin{array}{c}\text { Час } \\
\text { закінчення } \\
\text { дії }\end{array}$ & 苍 & 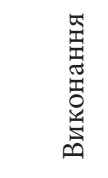 & 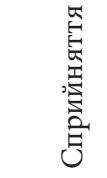 & 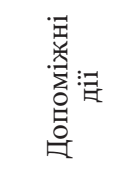 & 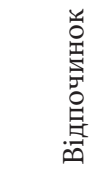 & 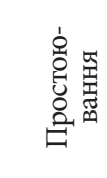 \\
\hline \multirow{23}{*}{ 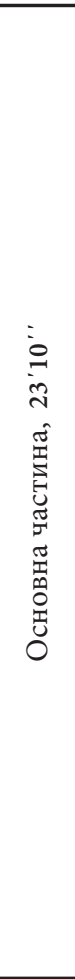 } & Перекиди & $23^{\prime} 20^{\prime \prime}$ & 18 & $2^{\prime} 00^{\prime \prime}$ & & & & \\
\hline & Перестроювання & $23^{\prime} 50^{\prime \prime}$ & & & & $0^{\prime} 30^{\prime \prime}$ & & \\
\hline & Пояснення учителя & $24^{\prime} 30^{\prime \prime}$ & 15 & & $00^{\prime} 40^{\prime \prime}$ & & & \\
\hline & Лазіння по канату & $25^{\prime} 00^{\prime \prime}$ & & $00^{\prime} 30^{\prime \prime}$ & & & & \\
\hline & Пояснення учителя & $24^{\prime} 30^{\prime \prime}$ & 15 & & $00^{\prime} 40^{\prime \prime}$ & & & \\
\hline & Лазіння по канату & $25^{\prime} 00^{\prime \prime}$ & & $0 \prime 30^{\prime \prime}$ & & & & \\
\hline & Відпочинок & $25^{\prime} 50^{\prime \prime}$ & & & & & $00^{\prime} 50^{\prime \prime}$ & \\
\hline & Лазіння по канату & $26^{\prime} 25^{\prime \prime}$ & & $0^{\prime} 35^{\prime \prime}$ & & & & \\
\hline & Пояснення учителя & $26^{\prime} 40^{\prime \prime}$ & & & $00^{\prime} 15^{\prime \prime}$ & & & \\
\hline & Лазіння по канату & $27^{\prime} 10^{\prime \prime}$ & 16 & $0 \prime 30^{\prime \prime}$ & & & & \\
\hline & Перестроювання & $27^{\prime} 50^{\prime \prime}$ & & & & $0^{\prime} 40^{\prime \prime}$ & & \\
\hline & Піднімання ніг на гімнастичній лаві & $28^{\prime} 15^{\prime \prime}$ & & $0^{\prime} 25^{\prime \prime}$ & & & & \\
\hline & Відпочинок & $28^{\prime} 35^{\prime \prime}$ & & & & & $0 \prime 20^{\prime \prime}$ & \\
\hline & Піднімання ніг на гімнастичній стінці & $29^{\prime} 00^{\prime \prime}$ & 17 & $0^{\prime} 25^{\prime \prime}$ & & & & \\
\hline & Відпочинок & $29^{\prime} 30^{\prime \prime}$ & & & & & $0^{\prime} 30^{\prime \prime}$ & \\
\hline & Піднімання ніг сидячи на підлозі & $30^{\prime} 00^{\prime \prime}$ & & $0 \prime 30^{\prime \prime}$ & & & & \\
\hline & Перестроювання на гру & $30^{\prime} 50^{\prime \prime}$ & 17 & & & $00^{\prime} 50^{\prime \prime}$ & & \\
\hline & Пояснення змісту і умов гри & $31^{\prime} 30^{\prime \prime}$ & & & $0^{\prime} 40^{\prime \prime}$ & & & \\
\hline & $\Gamma \mathrm{pa}$ & $36^{\prime} 50^{\prime \prime}$ & 22 & $55^{\prime} 00^{\prime \prime}$ & & & & \\
\hline & Підсумок гри & $36^{\prime} 50^{\prime \prime}$ & & & $0 \prime 20^{\prime \prime}$ & & & \\
\hline & Пояснення другого варіанта гри & $37^{\prime} 15^{\prime \prime}$ & & & $00^{\prime} 25^{\prime \prime}$ & & & \\
\hline & Гра & $39^{\prime} 30^{\prime \prime}$ & 20 & $2^{\prime} 15^{\prime \prime}$ & & & & \\
\hline & Imozo & & & $12^{\prime} 55^{\prime \prime}$ & $4^{\prime} 25^{\prime \prime}$ & $20^{\prime \prime}$ & $3^{\prime} 00^{\prime \prime}$ & \\
\hline \multirow{8}{*}{ 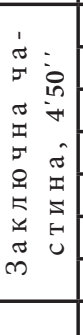 } & Перестроювання в колону по одному & $40^{\prime} 35^{\prime \prime}$ & & & & $0^{\prime} 25^{\prime \prime}$ & & \\
\hline & Ходьба & $40^{\prime} 15^{\prime \prime}$ & 16 & $0^{\prime} 40^{\prime \prime}$ & & & & \\
\hline & Вправи на дихання & $42^{\prime} 20^{\prime \prime}$ & & $1^{\prime} 05^{\prime \prime}$ & & & & \\
\hline & Вправи на поставу & $43^{\prime} 10^{\prime \prime}$ & 14 & $0^{\prime} 50^{\prime \prime}$ & & & & \\
\hline & Перестроювання в одну шеренгу & $43^{\prime} 50^{\prime \prime}$ & & & & $0^{\prime} 40^{\prime \prime}$ & & \\
\hline & Підсумок уроку, домашнє завдання & $45^{\prime} 00^{\prime \prime}$ & 13 & & 1'10' & & & \\
\hline & Imoro & & & $25^{\prime \prime}$ & $11^{\prime} 10^{\prime \prime}$ & $15^{\prime \prime}$ & & \\
\hline & Bcboro & $45^{\prime} 00^{\prime \prime}$ & & $27^{\prime} 10^{\prime \prime}$ & $6^{\prime} 05^{\prime \prime}$ & $6^{\prime} 05^{\prime \prime}$ & $3^{\prime} 00^{\prime \prime}$ & $20^{\prime} 40^{\prime \prime}$ \\
\hline
\end{tabular}

середньо на місці записують дані тільки в перших трьох графах (див. табл. 3.5).

У першій графі визначають частини уроку, відзначаючи точні межі часу їхнього початку і закінчення.

У другій графі «Види діяльності» записують зміст педагогічного процесу (наприклад: шикування, рапорт, слухання задач уроку, виконання конкретних вправ).

У третій графі записують час закінчення кожного фіксованого виду діяльності. Наприклад, на уроці на шикування треба було 2 хв 40 с, тому в даній графі вказують 2'40' '.

Після закінчення уроку на підставі обробки даних хронометражу визначають загальну і рухову (моторну) щільність.

Загальною щільністю називають відношення педагогічно виправданих витрат часу до тривалості уроку.
Руховою щільністю прийнято вважати відношення часу, використаного безпосередньо на будь-яку рухову діяльність учнями, до часу тривалості уроку.

Для обчислення загальної щільності уроку підсумовують раціональний час, витрачений на виконання рухових дій, сприйняття пояснень i демонстрації, перестроювання і підготовку місць занять. Потім отриману суму ділять на час, відведений на урок, і множать на 100. У нашому прикладі: $27^{\prime} 10^{\prime \prime}+6^{\prime} 05^{\prime \prime}+6^{\prime} 05^{\prime \prime}=39^{\prime} 20^{\prime \prime}=2360$

Загальна щільність уроку $=(2360 / 2700) \times 100=$ 86,7 (\%)

Для того щоб обчислити рухову щільність, підсумовують час, витрачений на виконання рухових дій. Далі отриману суму ділять на час, відведений на урок, і множать на 100. 
Після одержання даних загальної і рухової щільності уроку необхідно їх проаналізувати відповідно до задач, поставлених перед уроком, особливостей учнів і умов проведення уроку. Оцінку варто супроводити своїми рекомендаціями щодо засобів і шляхів підвищення загальної і рухової щільності даного уроку.

Для оцінки отриманих даних варто мати на увазі, що загальна щільність повноцінного уроку повинна наближатися до 100 \%, а зусилля, що учитель витрачає на усі види педагогічної діяльності, можуть бути цілком чи частково доцільними. У залежності від цього види діяльності учнів бувають раціональними і нераціональними. Педагогічно виправданими можна вважати лише ті, котрі необхідні для рішення задач даного уроку і виховання учнів.

До зниження загальної щільності уроку призводять такі причини:

- невиправдані простоювання на уроках (запізнення з початком, несвоєчасна підготовка місць занять, чекання черги перед виконанням вправи);

- непідготовленість вчителя до уроку;

- надмірна словесна інформація;

- незадовільна дисципліна учнів на уроці.

У залежності від типу і змісту уроку показник рухової щільності може змінюватися і досягати високого рівня. Так, на уроках закріплення техніки рухів і розвитку рухових здібностей вона може досягати 70-80\%. На уроках, де передбачене розучування рухових дій і формування знань, рухова щільність може знаходитися в межах 50-60\%. На уроках гімнастики рухова щільність коливається в межах $60-70 \%$.

Однак важливо знати, що показник моторної щільності не характеризує величину і характер фізіологічних зрушень в організмі. Так, найчастіше урокизмоторноющільністю $70 \%$ ібільшвикликають слабкі зрушення в роботі функціональних систем школярів (зокрема серцево-судинної: максимальна частота пульсу за урок менше 130 уд/хв). У такому випадку на уроці мала місце погана організація учнів і як наслідок, велика кількість перестроювань, підготовчих вправ низької інтенсивності, невиправданих переміщень і т.п. Ці дії враховуються у підрахунку моторної щільності, а отже, сприяють іiї підвищенню. Показник щільності росте, а навантаження залишається оціненим недостатньо точно.

Графік хронометражу і пульсометрії уроку варто виконувати на міліметровому папері, позначаючи усі види діяльності і простою (див. рис. 3.1).

Серед засобів і методів підвищення щільності уроку можна виділити наступні: своєчасна підготовка місць занять, устаткування й інвентарю; контроль за підготовкою учнів і організація початку уроку; попередній інструктаж і залучення в допомогу груповодів; широке застосування фронтального і кругового методів організації учнів; використання багатопропускних снарядів і пристосувань, а також саморобного дрібного інвентарю; стимулювання свідомої дисципліни, взаємодопомоги і колективізму.

Творчий підхід учителя до своєї роботи, ретельна і всебічна підготовка до уроку, постійне прагнення до вивчення передового досвіду забезпечать можливість більш раціонального використання часу на уроці і підвищать його ефективність.

Документ 8. Протоколи тестування рухової підготовленості школярів середніх класів.

Для тестування функціональної підготовленості школярів рекомендуються загальновідомі проби.

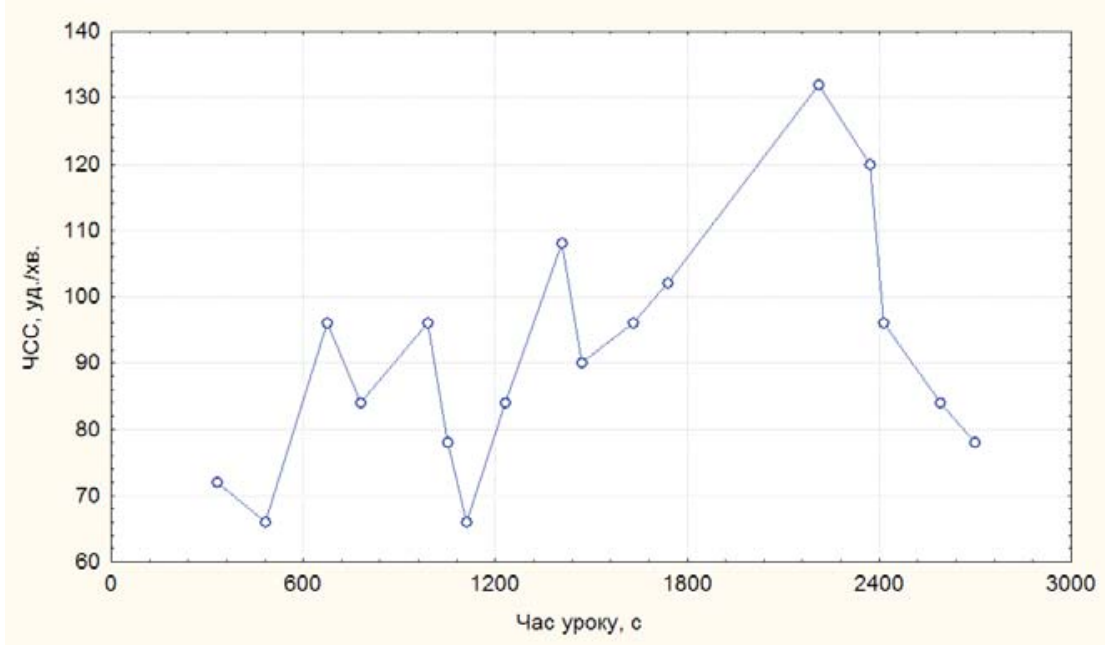

Рис. 3.1. Графік пульсометрії уроку 
A

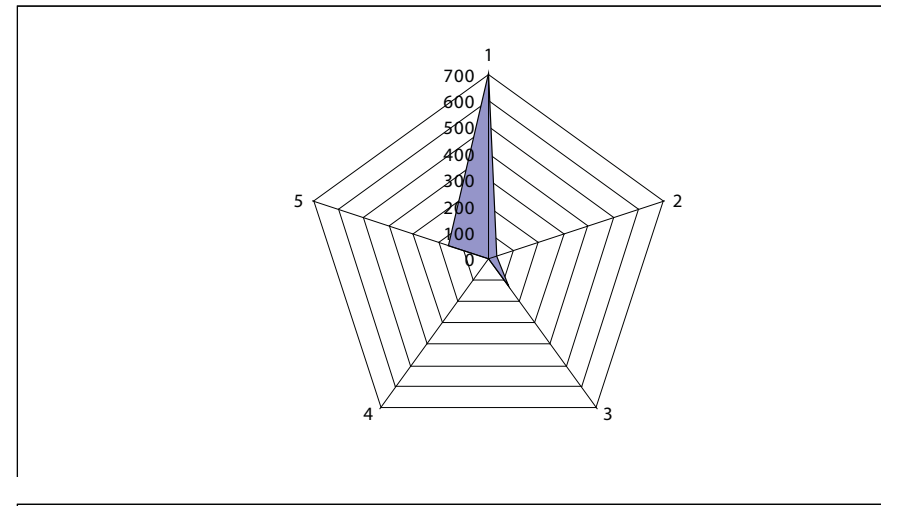

Б

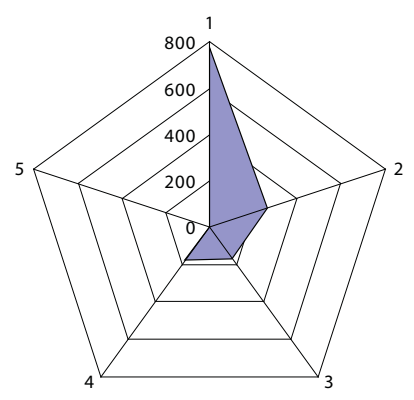

B

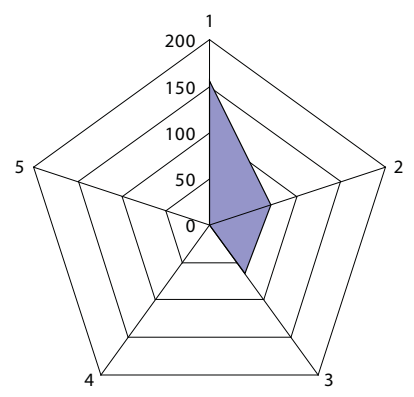

Рис. 3.2. Діаграма хронометражу уроку. А - підготовча частина, Б основна частина, В - заключна частина $(1-$ виконання вправи, $2-$ сприйняття, 3 - допоміжні дії, 4 - відпочинок, 5 - простоювання)

Проба Штанге. Учень в положенні сидячи робить глибокий вдих і видих, потім знову вдих (приблизно 80\% від максимального), закриває рот і одночасно затискає пальцями ніс, затримує дихання (секундомір включається в кінці вдиху і виключається з початком видиху). Здорові нетреновані люди здатні затримати дихання на 40-55 с, ті, які регулярно займаються фізичною культурою і спортом - на 60-90 с і більше. При втомі, перетренуванні час затримання дихання знижується.

Проба Генчі передбачає затримку дихання після видиху. Ї̈ї можна проводити не раніше, як через 5-7 хв після проби Штанге. Здорові нетреновані люди здатні затримати дихання на 25-30 с, добре підготовлені фізкультурники - 40-60 с і довше.

Проба Серкіна складається із трьох фаз. Спочатку визначається час затримки дихання на видиху в положенні сидячи, потім учень робить 20 присідань протягом 30 с і повторює затримку дихання, після цього 1 хв відпочиває і знову повторює затримку дихання в положенні сидячи (тобто повторюється перша фаза проби) (табл. 1).

Суттєве скорочення часу виконання проби вказує на погіршення функції дихання, а також кровообігу і нервової системи. При регулярних i вірно побудованих фізкультурних заняттях час затримки дихання повинен збільшуватися. 
Таблиия 1

\begin{tabular}{|c|c|c|c|c|}
\hline \multirow{2}{*}{$\begin{array}{l}\text { № } \\
3 / \Pi\end{array}$} & \multirow{2}{*}{$\begin{array}{c}\text { Контингент } \\
\text { досліджуваних }\end{array}$} & \multicolumn{3}{|c|}{ Фази проби } \\
\hline & & Перша & Друга & Третя \\
\hline 1 & Здорові треновані & $\begin{array}{l}60 \quad \text { i } \\
\text { більше }\end{array}$ & $\begin{array}{l}30 \text { i } \\
\text { більше }\end{array}$ & $\begin{array}{l}\text { більше } \\
60\end{array}$ \\
\hline 2 & Здорові нетреновані & $40-55$ & $15-25$ & $35-55$ \\
\hline 3 & $\begin{array}{l}\text { Особи з прихова- } \\
\text { ною недостатністю } \\
\text { кровообігу }\end{array}$ & $20-35$ & $\begin{array}{l}12 \text { і } \\
\text { менше }\end{array}$ & $\begin{array}{l}24 \mathrm{i} \\
\text { менше }\end{array}$ \\
\hline
\end{tabular}

Проби із затримкою дихання мають низку протипоказань, наприклад, запаморочення, тому їх необхідно проводити з обережністю.

Для оцінки рухової підготовленості школярів у період педагогічної практики рекомендуються нижченаведені тести.

\section{1. Стрибки з «надбавками».}

Обладнання. Обладнаний сектор для стрибків; крейда; калькулятор; рулетка.

Проведення тесту. Для кожного учасника тестування визначають максимальний результат у стрибках у довжину з місця. Потім за допомогою калькулятора обчислюють 50 і 75\% максимального стрибка. Креслять на відстані 50\% максималь- ного результату стрибка першу лінію. Для кращого орієнтування збоку встановлюють кубик. На відстані 75\% максимального результату стрибка накреслюють другу лінію. Тим самим визначають індивідуальний коридор стрибків 3 «надбавками».

Потім у межах даного коридору досліджувані виконують стрибки 3 «надбавками». Підрахунок надбавок припинявся, як тільки досліджуваний досягнув другої лінії, або якщо у двох стрибках, виконаних підряд, не збільшив довжину стрибка.

Результат. Кількість стрибків з «надбавками», що виконані у заданому коридорі.

Загальні вказівки та зауваження.

1. Виконувати стрибки з жорстким приземленням забороняється.

2. Для визначення максимального результату стрибка надається три спроби. Стрибки 3 «надбавками» виконуються два рази.

3. Для кращого розуміння виконання тесту надається попередня спроба.

2. Оцінка часових параметрів руху.

Обладнання. Секундомір.

Проведення тесту. За завданням тестолога випробовуваний виконує біг на місці у середньому

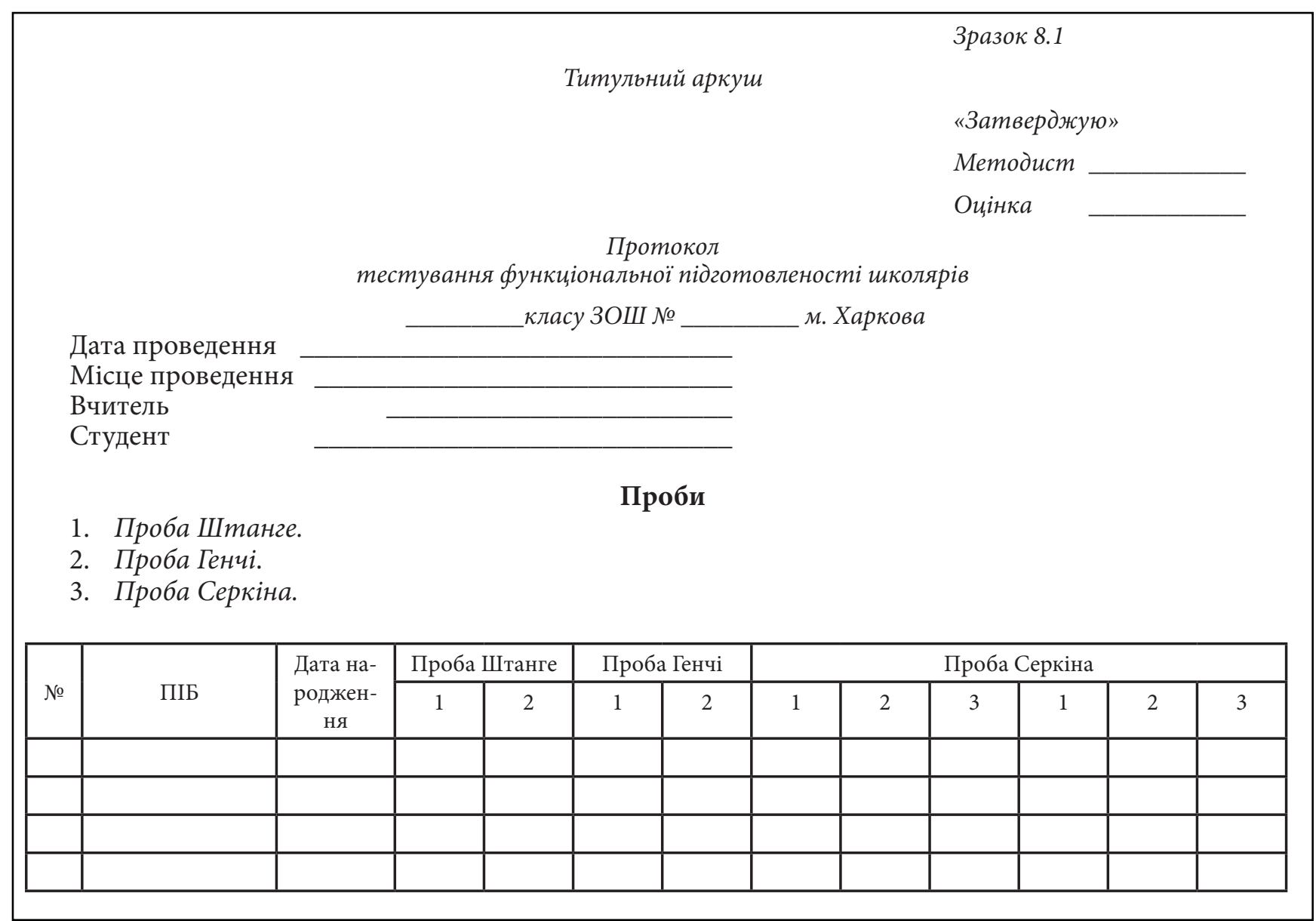


темпі, згинаючи коліна до прямого кута між стегном і гомілкою, протягом 5 с. Після цього учасник тестування відтворює тривалість часу бігу - 5 с. Тестолог перевіряє правильність відтворення часу бігу за секундоміром. Потім пропонується зробити те саме протягом 10, 30 і 60 с.

Результат. Відхилення, визначене з точністю до 0,1 с, відтворення часового інтервалу. Значення зі знаком «плюс» означає перевищення часового інтервалу, зі знаком «мінус» - недосягнення заданого часу.

Загальні вказівки та зауваження.

1. Учасник тестування не повинен підраховувати час.

2. Виконується тільки одна спроба.

3. Оцінка сприйняття силових параметрів рухів руками.

Обладнання. Кистьовий динамометр.

Проведення тесту. Досліджувані отримують завдання стиснути кистьовий динамометр 3 максимальним зусиллям. Після цього їм пропонується без зорового контролю стиснути динамометр з зусиллям, що дорівнює 1/3, 1/2 i $2 / 3$ максимального. Тест виконується обома руками.

Результат. Оцінюється точність відтворення зусилля, що дорівнювало $1 / 3,1 / 2$ та $2 / 3$ максимального (для кожного із досліджуваних воно було індивідуальним). Результат визначається з точністю до 1 кг. Розрахунок нормативів оцінки відхилення відтвореного зусилля визначається у відсотках.

Загальні вказівки та зауваження.

1. Для визначення максимального зусилля досліджувані виконують дві спроби. Реєструється кращий результат.

2. Дозоване зусилля виконується почергово правою і лівою рукою один раз.

\section{4. Човниковий біг $\mathbf{4 \times 9}$ м.}

Обладнання. Секундомір і рівна доріжка довжиною 9 м, обмежена двома паралельними лініями. За кожною лінією - 2 півкола радіусом 50 см з центром на лінії. Два дерев'яних кубика $(5 \times 5 \times 5$ см); реєстраційний стіл; стілець.

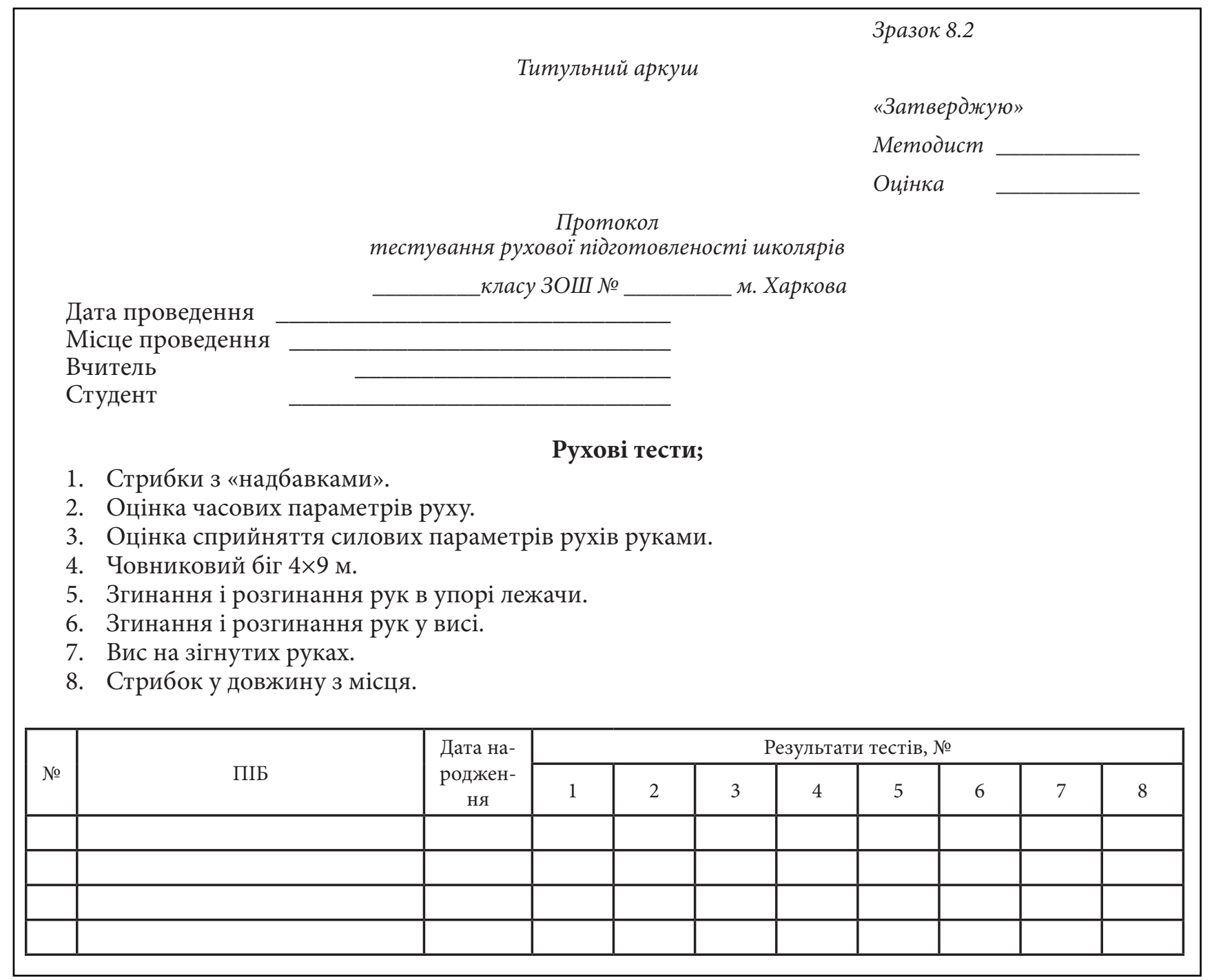


1. Кількість учнів: хлопчиків

Педагогічна характеристика функиіональної підготовленості

2. Кількість учнів: клас _ ЗОШ № м. Харкова

- $\quad$ які не виконують програму з фізичної культури

- які мають низький рівень функціональної підготовленості

3. Особливості планування та проведення уроку відповідно до характеристики класу:

- $\quad$ заходи корекції постави

- заходи щодо підвищення функціональної підготовленості учнів:

4. Відомості про відхилення у стані здоров'я:

\begin{tabular}{|l|l|l|l|}
\hline № 3/п & Прізвище, ім’я & Діагноз & $\begin{array}{l}\text { Обмеження навантаження на } \\
\text { уроці }\end{array}$ \\
\hline & & & \\
\hline & & & \\
\hline
\end{tabular}

Методист

Студент

Зразок 8.4

1. Кількість учнів: хлопчиків

Педагогічна характеристика рухової підготовленості

2. Кількість учнів:

- $\quad$ які не виконують програму з фізичної культури

- які мають низький рівень координаційної підготовленості

- які мають низький рівень силової підготовленості

3. Особливості планування та проведення уроку відповідно до характеристики класу:

- $\quad$ заходи корекції постави

- заходи щодо підвищення рухової підготовленості учнів:

4. Відомості про відхилення у стані здоров'я:

\begin{tabular}{|l|l|l|l|}
\hline$№$ 3/п & Прізвище, ім’я & Діагноз & $\begin{array}{l}\text { Обмеження навантаження на } \\
\text { уроці }\end{array}$ \\
\hline & & & \\
\hline & & & \\
\hline
\end{tabular}

Методист

Студент

Проведення тесту. За командою «На старт!» учасник тестування стає у положення високого старту перед стартовою лінією. За командою «Марш!» у максимальному темпі пробігає 9 м до другої лінії, бере один із двох дерев'яних кубиків, що лежать у півколі, бігом повертається назад і кладе його в стартове півколо (кидати кубик не можна), знову біжить у зворотному напряму, повертається з другим кубиком і кладе його у стартове півколо. На цьому тест закінчується.
Результат. Час, зафіксований з точністю до 0,1 с з моменту старту до моменту, коли учасник поклав другий кубик у півколо.

Загальні вказівки та зауваження.

1. Кожному учаснику надається дві спроби. До протоколу заносять кращий або середній результат, розрахований із двох спроб.

2. Спроба не зараховується, якщо випробовуваний кидає або впускає кубик у півколо. Його слід акуратно покласти. Якщо ця ви- 
мога не виконується, то надається повторна спроба.

3. Доріжка, на якій проводиться човниковий біг, має бути рівною, у хорошому стані, не слизькою.

5. Згинання і розгинання рук в упорі лежачи.

Обладнання. Рівний дерев'яний або земляний майданчик.

Проведеннятесту. Учасниктестування приймає положення упору лежачи: руки випрямлені, на ширині плечей пальцями вперед, тулуб і ноги утворюють пряму лінію, пальці ступнів спираються об підлогу. За командою «Можна!» учасник починає ритмічно з повною амплітудою згинати і розгинати руки.

Результат. Кількість безпомилкових згинань і розгинань рук за одну спробу.

Загальні вказівки і зауваження. У згинанні рук необхідно торкатися грудьми опори. Не дозволяється торкатися опори стегнами, згинати тіло і ноги, перебувати у вихідному положенні та із зігнутими руками більше 3 секунд, лягати на підлогу, розгинати руки почергово, розгинати і згинати руки не з повною амплітудою. Згинання і розгинання рук, виконані 3 помилками, не зараховуються.

\section{6. Згинання і розгинання рук у висі.}

Обладнання. Перекладина.

Проведення тесту. Учасник тестування набирає положення вису, руки випрямлені, тулуб і ноги утворюють пряму лінію. За командою «Можна!» учасник починає ритмічно з повною амплітудою згинати і розгинати руки.

Результат. Кількість безпомилкових згинань і розгинань рук за одну спробу.

Загальні вказівки і зауваження. У згинанні рук необхідно наблизитися до точки вису плечима. Не дозволяється перебувати у вихідному положенні та із зігнутими руками більше 3 секунд. Згинання і розгинання рук, виконані з помилками, не зараховуються.

7. Вис на зігнутих руках.

Обладнання. Перекладина, секундомір, гімнастичні мати.

Проведення тесту. Учасник тестування за допомогою набирає положення вису на зігнутих руках, тулуб і ноги утворюють пряму лінію, підборіддя знаходиться вище перекладини. За командою «Можна!» учасник утримує це положення.

Результат. Час у секундах протягом якого утримується вис на зігнутих руках.

Загальні вказівки і зауваження.

1. Виконання тесту припиняється, якщо учень опускає підборіддя нижче перекладини.

2. Хват руками повинен бути на ширині плечей.
8. Стрибок у довжину з місця.

Обладнання. Неслизька поверхня 3 лінією i розміткою в сантиметрах.

Проведення тесту. Учасник тестування стає носками перед лінією, поштовхом ніг і змахом рук - стрибає вперед якомога далі.

Результат. Дальність стрибка в сантиметрах у кращій $з$ двох спроб.

Загальні вказівки і зауваження. Тестування проводиться відповідно до правил змагань для стрибків у довжину з розбігу. Місце відштовхування і приземлення повинні перебувати на одному рівні.

Резудьтати тестування реєструються у протоколи і на їх основі дається педагогічна характеристика рухової підготовленості школярів (див. зразок 8.1; $8.2 ; 8.3 ; 8.4)$.

Документ 9. Протокол обговорення залікового (контрольного) уроку (див. зразок 9).

Контрольні уроки проводяться на останньому тижні практики. Для оцінки уроку використовується загальновідомі схеми і результати хронометрування.

\section{План педагогічного спостереження за уроком фізичної культури}

\section{І. Підготовленість учителя до уроку}

Підготовленість педагога до майбутнього уроку частково визначають шляхом попереднього вивчення плану, записів у класному журналі про проходження навчального матеріалу і поточної успішності учнів. У разі потреби окремі питання з'ясовують у короткій бесіді з учителем. Вирішальним є спостереження за його діями в процесі уроку.

Найбільшістотним увизначенніпідготовленості педагога до уроку вважається виявлення наступних моментів:

\section{А. Наявність плану уроку і правильне його оформлення.}

\section{Б. Визначення задач уроку.}

Відповідність намічених задач програмним вимогам (загальношкільним задачам фізичного виховання, навчальним вимогам даного класу). Ступінь конкретизації задач; відображення в них логічного зв'язку з попереднім уроком; ступінь повноти і розмаїтості задач з погляду вимог усебічного, гармонійного виховання; можливості рішення намічених на даний урок задач; їхнє мотиваційне значення (спонукання школярів до навчання, подолання труднощів, переконання їх у важливості досліджуваного, підвищення інтересу до уроку).

\section{В. Розробка предметного змісту уроку.}

Відповідність намічених засобів плану на семестр і задачам даного уроку; методична 
Протокол

обговорення контрольного уроку з фізичної культури (баскетбол) студента-практиканта IV курсу 42 групи факультету фізичної культури ХНПУ імені Г.С.Сковороди Микулінського Олексія Івановича проведеного 17.02.10 в 7-А класі гімназії № 55 м. Харкова

Присутні: Лукаш Людмила Вікторівна - вчитель фізичної культури; методист факультету; студентипрактиканти: Омельченко Д. С., Назаренко В. М., Богдан І. О., Гаврилюк К. М., Ходунова M. I.

Слухали:

1. Студента-практиканта Микулінського Олексія Івановича - з самоаналізом, у якому зазначив, що урок було проведено згідно конспекту, поставлені завдання виконані в повному обсязі, відмітив високу емоційну забарвленість уроку.

Виступили:

1. Лукаш Людмила Вікторівна, вчитель середніх та старших класів гімназії № 55 м. Харкова - наголосила на тому, що урок пройшов з великою зацікавленістю з боку учнів, розпочався вчасно і всі частини його проходили у відповідності до хронометражу та виду діяльності. Всі вправи, використані на уроці, відповідали поставленим завданням.

2. Омельченко Дмитро Сергійович, студент-практикант факультету фізичної культури ХНПУ ім. Г. С. Сковороди - звернув увагу присутніх на якісно проведену практикантом розминку та правильно підібрані вправи для вирішення завдань основної частини уроку.

3. Методист бригади - інформація про правильне виконання задач, поставлених перед уроком, про демонстрацію знань програмового матеріалу з модулю «Баскетбол» для учнів 7-х класів; звернув увагу на чітку витриманість структури уроку та час проведення окремих його частин.

Наголосив на незначні недоліки при проведенні уроку: відпрацювання практикантом командного голосу, деякі неточності в поясненні ЗРВ, відведення більшої к-ті часу на розслаблення м'язів та поновлення організму після проведеної двосторонньої гри.

Ухвалили: оцінити контрольний урок студента-практиканта Микулінського О. І. на 5 («відмінно»).

Вчитель фізичної культури

Методист

Студент-практикант

Микулінський О. I.

доцільність викладеної послідовності вправ в уроці; наявність переліку необхідного наочного приладдя і технічних засобів, їхня повнота і методична цінність.

Г. Розробка методів і методичних прийомів навчання, виховання, організації й оцінки успішності учнів.

Відповідність наміченим задачам, особливостям учнів, умовам роботи; цінність 3 погляду усебічного виховання особистості.

\section{Д. Мовна і рухова підготовленість педагога.}

Ясність і стислість мовного спілкування; правильність і чіткість команд, регулювання темпу рухів; дохідливість формулювань, вимог, правил; логічна стрункість і необхідна образність розповіді, бесіди про спортивну подію і т.п.; уміння користуватися інтонаціями голосу, жестом, мімікою й ін.

Технічна підготовленість до виконання рухів, прийомів підтримки і страховки; відповідність одягу і взуття умовам проведення занять, вправам, які демонструються, естетичним і гігієнічним вимогам.

\section{Е. Підготовленість до уроку помічників.}

Озброєність знаннями й уміннями організаційно-методичного характеру (знання призначення вправ і уміння правильно їх виконувати; знання помилок у техніці рухів і уміння їх виправляти, а також страхувати, надавати допомогу; знання правил гри, вимог до установки снарядів тощо); наявність (чи відсутність) попереднього інструктування помічників, його зміст. 
Ж. Загальна оцінка підготовленості педагога до уроку.

Відповідність здійсненого на уроці наміченому в плані, уміння користуватися планом, ступінь виправданості (чи невиправданості) допущених відступів у задачах, змісті і методиці занять (з облікомсформованих упроцесі навчально-виховної роботи реальних умов і ситуацій). Достатність (чи недостатність) виявлених у процесі викладання власних знань, рівня рухової культури і методичних умінь.

\section{II. Навчальна діяльність вчителя й учнів}

Основною задачею спостереження й аналізу даного питання є характеристика й оцінка організаторських здібностей, знань і умінь вчителя, який проводить урок. При цьому важливо уникнути захоплення лише зовнішньою стороною організаторських проявів, їхньою формальною ефективністю. Головним $\epsilon$ визначення їхньої педагогічної доцільності, відповідність конкретним навчально-виховним ситуаціям і актуальним у даний момент задачам навчання і виховання.

\section{А. Організація матеріально-технічних умов.}

Попереднє прибирання місць занять, провітрювання навчального приміщення; перевірка справності, установка і прибирання снарядів; розподіл і збір дрібного інвентарю; переміщення й установка важких снарядів. Забезпечення безпеки занять; приучення учнів, що займаються, до дбайливого використання суспільного майна; виховання дисциплінованості, передбачливості, організованості, працьовитості, розвиток естетичних почуттів, прагнення до високої культури виконання доручень і взаємин.

\section{Б. Розміщення і переміщення учнів.}

Доцільністьобранихформрозміщенняіспособів переміщення для виконання чергових завдань 3 погляду забезпечення оптимальних просторових умов роботи (гарної видимості педагога, зручності виконання фізичних вправ, взаємо-спостереження учнів, огляду педагогом усіх учнів), а також економії часу. Виховна цінність застосовуваних перестроювань (розвиток орієнтування в просторі і в часі, виховання естетичних почуттів, уваги, зібраності і ретельності). Дотримання вимог до проведення гімнастичних перестроювань і стройових вправ (у відношенні їхніх форм, командної мови).

\section{В. Організація навчальної роботи.}

Види організації навчальної роботи (фронтальна, групова, кругова, індивідуальна), їхні варіанти - одночасне виконання вправи і пов'язаних 3 ним завдань у парах, трійках, коли один виконує, а інший (або двоє) надає підтримку, страхує чи веде спостереження, оцінює, дає вказівки; позмінне виконання вправи «хвилями» по 4-6 чоловік (і більше) у залежностівіднаявностіснарядів, дрібного інвентарю, місця; потокове виконання вправи - один слідом за іншим; варіанти кругової форми організації занять. Організація індивідуальної навчальної роботи учнів, використання іiі варіантів. Доцільність використаних форм організації занять, дотримання основних вимог до їхнього застосування; рівень практичних умінь вчителя в організації навчально-виховної роботи й забезпечення належної іï ефективності.

Г. Організація роботи відповідальних керівників і виконавців (фізкультурних організаторів, чергових, капітанів команд, суддів, виконавців разових доручень, груповодів).

Ступінь підготовленості цих осіб до виконання своїх обов'язків, зміст і способи виконання доручень, успішність їхньої діяльності.

Контроль і оцінка педагогом роботи помічників, забезпечення свідомого підпорядкування учнів відповідальним особам і своєчасної допомоги їм у скрутних випадках (із проявом при цьому необхідного такту і люб'язності). Дотримання педагогом вимог періодичної зміни помічників. Виховні досягнення педагога в організації діяльності своїх помічників.

Д. Формування в учнів навичок свідомого аналізу рухових дій, самоконтролю i самооцінки навчальної роботи.

Достатність (чи недостатність) створюваних педагогом умов для самостійного ведення спостережень, виконання вправ і прояву учнями розумової активності (визначення педагогом пріоритетних задач спостережень і самостійних дій учнів, виділення необхідного для цього часу, повідомлення попередніх знань; організація умов діяльності учнів, попередження можливих помилок).

Збереження педагогом керівної ролі в процесі самостійних дій учнів: контроль за їхніми діями, спонукання до самоконтролю, корекція самооцінок; своєчасна консультативна допомога, попередження помилкових дій, зосередження уваги на недостатньо засвоєних характеристиках техніки рухів, на недоліках в орієнтовних діях і застосуванні засвоєних раніше знань і умінь; спільне з учнями формулювання закономірностей навчання руховим діям, що виявляються в процесі рухової діяльності; визначення правил парних і інших колективних дій, питань взаємоконтролю і критеріїв взаємооцінок; стимулювання і заохочення пошукових і творчих зусиль; підсумкова оцінка поводження учнів, самостійних дій і їхніх результатів. 


\section{Е. Забезпечення послідовності в навчанні.}

Під час спостереження й аналізу особливо важливо простежити в процесі уроку, як зміст навчання (те, чому і як навчає педагог, і як навчаються його учні) дійсно перетворюється в реальні досягнення (конкретні знання, уміння і навички, розуміння засвоєного, приріст духовних і фізичних сил, рухових можливостей, поліпшення поведінки тощо).

Ступінь відповідності основного змісту уроку програмним вимогам і навчальному матеріалу для даного класу. Достатність (чи недостатність) обліку наявних знань, умінь і навичок в учнів для призначення чергових завдань.

Забезпечення зв'язку нового матеріалу з пройденим на попередніх уроках, логічність зв'язку основної вправи з підготовчими і підвідними; обгрунтованість послідовного акцентування на окремі задачі навчання; наявність і своєчасність перевірки якості засвоєного, достатність зусиль по усуненню виявлених недоліків, помилок; обгрунтованість закріплення позитивних досягнень, забезпечення міцності засвоєного; доцільність запропонованих домашніх завдань.

\section{Ж. Реалізація вимог доступності навчання.}

Дотримання основної установки сучасної дидактики - забезпечення посильності завдань в разі високої напруги сил і здібностей у зв'язку з подоланням труднощів навчальної роботи, доцільність і результативність запропонованої педагогом міри інтелектуальних, вольових і фізичних зусиль, обумовлених складністю завдань, навчального матеріалу і конкретних навчальних дій, а також необхідною інтенсивністю і тривалістю навчальної роботи; ступінь обліку стану здоров'я учнів.

Увага педагога до організації оптимальних умов навчальної діяльності і реалізації пізнавальних можливостей учнів.

Уміння забезпечити продумані переходи від більш відомого, цікавого і захоплюючого, від більш простого - до нового, що не стало ще особистою потребою, до більш складного, важкого, мало емоційного, стомлюючого; уміння вносити в напружену роботу елементи необхідного відволікання, переключень, заспокоєння, тимчасового відпочинку чи відновлення уваги, регуляції дихальної і серцево-судинної функції, нової мотивації необхідних напруг.

\section{3. Забезпечення індивідуального підходу до учнів.}

Облік педагогом вікових і статевих розходжень між хлопчиками і дівчатками у визначенні навчальних завдань і навантажень, виборі методичних прийомів навчання і виховання, організації й оцінки навчальної діяльності; увага до рівня підготовленості, інтересів, можливостей окремих груп класу й учнів.

Стимулювання і послідовний розвиток індивідуальних здібностей учнів, підтримування творчої ініціативи, тактовне усунення недоліків у фізичному розвитку, рухових проявах і поведінці; уміння сполучити колективне навчання основам техніки рухів і застосування їх у різних умовах 3 індивідуалізованим освоєнням деталей техніки і варіантів рухових дій.

Конкретні досягнення в диференціації й індивідуалізації навчальних завдань, прийомів педагогічних впливів на уроці; уміння забезпечувати в цілому колективний характер навчання i відповідні виховні впливи на взаємини і поведінку учнів.

\section{III. Висновок і пропозиції по уроку}

Загальна характеристика уроку і педагога. Ступінь рішення намічених задач уроку, загальний рівень виховних, загальноосвітніх і гігієнічних досягнень педагога (високий, задовільний, низький). Головні недоліки і помилки, допущені в методиці навчання і виховання.

Особисті якості педагога (зовнішній вигляд, уміння триматися, вимогливість, рішучість і послідовність у діях, витримка, такт); знання і розуміння дітей, навчального матеріалу, методів навчання і виховання; уміння орієнтуватися в навчальних ситуаціях і поводженні дітей, оперативно застосовувати свої знання й уміння, творчо переборювати труднощі, які негадано виникли. Найбільш істотні недоліки педагога: виявлені пробіли в знаннях, практичних уміннях, недоліки у відносинах 3 учнями. Загальний професійно-педагогічний рівень педагога.

Аналіз уроку рекомендується починати із самооцінки вчителем свого уроку. Це важливий показник того, чи бачить сам педагог позитивні й особливо негативні сторони проведеного ним уроку, i чи зможе він самостійно працювати над удосконалюванням своєї професійної підготовки.

У ході розбору уроку необхідно з'ясувати, які у вчителя були міркування під час використанні тих чи інших вправ, методів навчання й організації учнів, при цьому необхідно не нав' язувати учителю своїх поглядів. Дуже важливо, щоб розбір уроку був проникнутий почуттям доброзичливості, проводився об'єктивно і професійно.

Варто дати загальну оцінку уроку (відмінно, добре, задовільно чи незадовільно), а також рекомендації педагогу (найбільш актуальні на даному етапі пропозиції за методикою навчання i виховання, відношенню до учнів, самоконтролю, самоосвіти). 
Документ 15. Звіт про проходження практики.

3BIT

про проходження педагогічної практики студента-практиканта

IV-го курсу 42 групи

факультету фізичної культури ХНПУ

ім. Г.С. Сковороди

Микулінського Олексія Івановича

\section{I. Організаційна робота.}

Відповідно до навчального плану педагогічну практику проходив у 7-А класі гімназії № 55 Київського району м. Харкова у період 318 січня по 20 лютого 2010 року, у якості учителя фізичної культури.

Напередодні практики був присутнім на настановчій конференції з педагогічної практики, на якій було повідомлено про задачі практики, основні вимоги до практикантів та необхідну звітну документацію по ії закінченні.

На методичних нарадах в школі ставились конкретні педагогічні завдання на тиждень, перевірялась звітна документація, присутність та проведення занять, що, безумовно, позитивно вплинуло на ввесь хід практики.

Методичні поради та допомогу у плануванні практичної роботи я отримував з боку викладачів фізичної культури школи та з боку методиста від факультету. Педагогічний колектив школи - це досвідчені фахівці. Вони завжди, всім без виключення, надавали методичні поради практикантам.

\section{II. Технічна база.}

Школа має 3 спортивних зали (1 ігровий та 2 малих спортивних зали для молодших класів), стадіон, ігрові майданчики для волейболу та баскетболу. Спортивна база дозволяє школі та ії вчителям на належному рівні виконувати усі розділи шкільної програми з фізичної культури. Шкільний спортивний інвентар та спортивні споруди належно підготовлені для роботи з дітьми.

Програмовий матеріал з фізичної культури планується згідно з навчальної програми з фізичної культури для загальноосвітніх навчальних закладів. Шкільна програма, як і належить, складається 3 двох інваріантних модулів (теоретико-методичні знання, загальна фізична підготовка) та декількох варіативних модулів.

\section{III. Навчально-методична робота.}

Присутність на установчій конференції з педпрактики на факультеті, участь у щотижневих нарадах бригади у школі, а також створений нами «Куточок практиканта» допомогли мені своєчасно і якісно скласти необхідну навчальну документацію. За час проходження практики провів 8 уроків 3 фізичної культури у 7-А класі з модулю «Баскетбол».
При проведенні уроків використовував традиційні методи організації учнів: груповий, загінний (по відділенням), поточний, індивідуальний та наступні методи навчання: словесний, наочний, практичний та контролю і оцінки учнів у оволодінні навчальним матеріалом.

Позитивним моментом у проведенні навчальної роботи під час педагогічної практики було: присутність бригади на «показових уроках», які для нас провели вчителі фізичної культури на I тижні практики, допомога у проведені членам бригади та вчителям школи, обговорення цих уроків. Дуже також допомогла та навчально-методична підготовка, яку ми отримали на факультеті під час занять зі спортивних ігор.

Установлена для практикантів «норма» - щоденно проводити 2-3 уроки в інших класах, крім закріпленого методистом факультету, підвищила нашу навчальну підготовку. Перевірка конспектів уроків та методичні поради вчителів фізичної культури і методиста Худолія О. М. перед уроком давала можливість почувати себе впевнено при проведенні занять.

\section{IV. Спортивно-масова робота.}

Під час проходження практики я ознайомився 3 організацією та проведенням спортивно-масової роботи у школі. Також відвідав заняття шкільної спортивної секції з футболу, склав робочий план занять.

Проходження нами практики співпало 3 проведенням у всіх школах міста Харкова «Малих Олімпійських ігор - Діти Харкова».

У цих змаганнях беруть участь 70\% школярів, а це 2600 класів з 3800 класів шкіл нашого міста. За програмою Олімпіади змагалися діти 3-8 класів, а у змаганнях школярів 7-8 класів брали участь i їх батьки. Вся наша бригада практикантів брала активну участь у підготовці та проведенні яскравого відкриття та цікавого проведення змагань «Малих Олімпійських ігор», першості школи 3 міні-футболу. Участь у цих заходах допомогли мені поглибити знання з організації та проведення дитячих змагань.

\section{V. Виховна робота.}

Я щотижня відвідував виховні години у закріпленому за мною класі. Ознайомився із «Планом виховної роботи класного керівника на II півріччя», що допомогло мені обрати тему для проведення звітного виховного заходу у класі.

Відвідував також уроки свого класу з інших предметів з метою вивчення досвіду роботи вчителів школи та проведення психолого-педагогічних спостережень для складання характеристики на обраного мною учня.

Заліковим виховним заходом, який я провів 3 класом була пізнавальна бесіда «Загартовування 
та його вплив на організм». Складання психологопедагогічної характеристики на учня, за яким я стежив, теж було звітним документом.

I все ж таки, я глибоко переконаний, що кращим уроком для виховання учнів є урок фізичної культури. Саме на цих уроках їх привчають до праці, у спортивній боротьбі вчать поважати один одного, віддавати усі свої сили та енергію заради перемоги своєї команди, бути чесним у спортивній боротьбі, дотримуватися правил гігієни та техніки безпеки, привчають слідкувати за своїм здоров'ям, берегти та зміцнювати його, бути охайним, бадьорим i впевненим у своїх можливостях та силі.

\section{VI. Висновки та пропозиції.}

Матеріально-технічна база школи та педагогічний колектив дозволяють виконувати державну програму з фізичної культури, а практикантам - набути необхідних навичок та досвіду для майбутньої професійної діяльності. Знання та практичні навички придбані в університеті дозволили мені відчувати себе впевнено і ефективно виконувати завдання педагогічної практики. За період практики мною була розроблена та складена наступна документація:

- $\quad$ річний план-графік проходження навчального матеріалу;

- тематичний план зі спортивних ігор (модуль «Баскетбол»);

- 8 конспектів уроків (2 розгорнуті);

- $\quad$ комплекси ЗРВ, рухливі ігри та естафети;

- індивідуальний план;

- робочий план занять секції з футболу на IIге півріччя;

- календарний план спортивно-масової роботи школи на II півріччя;

- положення (сценарій) спортивно - масового заходу;

- виховний захід 3 протоколом його обговорення;

- психолого-педагогічну характеристику учня;

- $\quad$ звіт про проходження практики;

- щоденник педагогічних спостережень.

Безумовно, що момент проходження педагогічної практики в школі це можливість конкретно попрацювати 3 дітьми, перевірити на практиці набуті за роки навчання теоретичні знання, це можливість робити спостереження, оцінювати їх знання, вміння, навички, фізичну підготовку і перш за все - займатися їх вихованням.

На мій погляд, нам в університеті необхідно приділяти більше уваги і часу вмінню вести саме виховну роботу зі школярами, адже це чи не найважливіший аспект в становленні особистості. Також я вважаю, що нам слід ще більше вдосконалюватися у напрямі планування навчального матеріалу 3 фізичної культури, оформленні звітних документів.

20. 02.10

Микулінський О. I.

Таким чином, в роботі представлена програма педагогічної практики у середніх класах, а також зразки звітної документації, виконаної студентами практикантами.

\section{Список літератури}

1. Воробйов М.І. Практика в системі фізкультурної освіти: Навчальний посібник / Воробйов M.I., Круцевич Т.Ю. - Київ: Олімпійська література, 2006. - $191 \mathrm{c}$.

2. Терентьєва Н.М., Масляк І.П., Мамешина М.А. Педагогічна практика в школі: Навчальний посібник / Терентьєва Н.М., Масляк I.П., Мамешина М.А. - Харків: ХДАФК, 2009. - 208 с.

3. Педагогічна практика студентів / за ред. проф. А.Д. Бондаря. - Київ: «Вища школа», 1972. — 251 с.

4. Педагогическая практика в школе / Балбенко С.Ю., Васин Ю.Г., Медведев В.Ф., Мирошниченко В.И. - Киев: «Выща школа», 1990. - 136 с.

5. Педагогическая практика студентов физического воспитания: Прогр. пед. ин-тов. - М., 1986.

6. Положення про практику студентів вищих навчальних закладів (проект) / Режим доступа mon.gov.ua/images/gr/obg/.../proekt_ pologenia_09_02_2011.doc

7. Фізична культура в школі: Методичний посібник / за загальною редакцією С.М. Дятленка. - К.: Літера ЛТД, 2009. - 176 с.

Надійшла до редакиії 15.08.2011 p.

Худолей О.Н., Иващенко О.В. Педагогическая практика в школе. Сообщение II.

Аннотация. В статье рассматривается программа педагогической практики в средних классах общеобразовательной школы. Конкретизируются: цель и задание практики, длительность и сроки проведения, обязанности практикантов, содержание работы, перечень отчетной документации. Приводятся образцы оформления отчетной документации и объяснения к ее упорядочиванию.

Ключевые слова: педагогическая практика, программа, документы планирования.

Khudolii O.N., Ivashenko O.V. Pedagogical practice is at school. Report II.

Annotation. In the article the program of pedagogical practice is examined in the middle classes of general school. Specified: aim and task of practice, duration and terms of realization, duties of practice, maintenance of work, list of current documentation. Standards over of registration of current documentation and explanation are brought to her arrangement. Keywords: pedagogical practice, program, planning documents. 